\title{
Carbon Dioxide Emission from Streams and Rivers as an Integrative Part of Terrestrial Respiration
}

\author{
Shaoda Liu* \\ Department of Geography, National University of Singapore, Singapore
}

Submission: April 26, 2019; Published: May 13, 2019

*Corresponding author: Shaoda Liu, Department of Geography, National University of Singapore, 117570, Singapore \& Yale School of Forestry and Environmental Studies, New Haven, Connecticut

\begin{abstract}
Streams and rivers emit significant $\mathrm{CO}_{2}$ to the atmosphere and are ecologically heterotrophic receiving carbon inputs from the terrestrial ecosystem. Despite close coupling between two ecosystems, $\mathrm{CO}_{2}$ emission from streams and rivers has never been integrated or compared to other terrestrial carbon fluxes. Here a framework integrating stream and river $\mathrm{CO}_{2}$ emission to terrestrial carbon fluxes was proposed for a better perspective of the role of streams and rivers in global carbon cycle. Using terrestrial net primary product (NPP) as the base for comparison, it is found that streams and rivers emitted more carbon than expected from their areal extent on the landscape. This elevated role of streams and rivers in releasing terrestrial carbon to the atmosphere is believed to result from a disproportional transfer of terrestrial carbon (both organic and gaseous) to the inland waters. Correlations between riverine carbon emissions and areal extent of the flowing waters suggest a hydrologydriven mediation of terrestrial carbon release by streams and rivers.
\end{abstract}

Keywords: Carbon dioxide; River; Global carbon cycle; Inland waters; Terrestrial respiration

\section{Short Communication}

Streams and rivers participate in the global biogeochemical cycle of carbon not only by laterally transferring carbon from the terrestrial landscape to inland waters but also transforming and releasing large quantities of carbon as $\mathrm{CO}_{2}$ to the atmosphere [1-7]. Oversaturated $\mathrm{CO}_{2}$ in inland waters is either internally produced from aquatic organic carbon degradation or externally flushed from catchment soils [7-9]. From an aquatic ecology point of view, inland waters are net heterotrophic because they mostly release significantly more $\mathrm{CO}_{2}$ as a respiration product than they assimilate $\mathrm{CO}_{2}$ through in situ aquatic primary production $[10,11]$. As both river organic carbon and excess $\mathrm{CO}_{2}$ are dominantly from the terrestrial landscape, heterotrophy in aquatic ecosystems must not be viewed individually as an independent process but collectively as part of a larger biogeochemical cycle. From the point of view of a coupled biogeochemical cycle, net heterotrophy and excess $\mathrm{CO}_{2}$ emission from inland waters represent a part of the terrestrial respiration that is no more distinguishable from the rest of terrestrial carbon fluxes (e.g., heterotrophic soil respiration) [5-12]. However, while a few studies propose to link the aquatic $\mathrm{CO}_{2}$ emission to terrestrial carbon fluxes $[11,13,14]$, no systematic comparison has been made between the magnitude of aquatic $\mathrm{CO}_{2}$ emission and terrestrial carbon fluxes from the perspective of a combined biogeochemical cycle of carbon on land and in inland waters.

Herein I propose a framework that integrates $\mathrm{CO}_{2}$ emission from streams and rivers to carbon fluxes of the terrestrial ecosystem. Essentially, magnitudes of $\mathrm{CO}_{2}$ emission from regional rivers were compared with net primary production (NPP) of their coupled terrestrial ecosystem (i.e., ratio of carbon emission from rivers to regional NPP, Table 1). Importance of carbon emission from the rivers with respect to the terrestrial carbon fluxes was further assessed using an elevation ratio (ER) defined as the ratio of riverine carbon emission to regional NPP, divided by the ratio of the areal extent of the river network to total land area of the study region/catchment (see footnote of Table 1). $\mathrm{CO}_{2}$ emission estimates from rivers were made by independent authors by scaling up multi-location emission rates to the whole study region/catchment and compiled here for analysis. The assumption is that from the perspective of an integrated terrestrial and aquatic carbon cycle, terrestrial NPP 
represents the maximum amount of ecosystem products that are available for heterotrophic respiration in both terrestrial ecosystem and linked aquatic ecosystems $[15,16]$.

The elevation ratio (ER) calculations show that the reviewed river networks, covering eight orders of magnitude in land area, exhibited higher carbon emission to terrestrial NPP ratios than indicated by the areal extent of their fluvial channels on land (i.e., ER > 1; Table 1). Elevation ratios also varied greatly at different spatial scales and climate zones. For example, small catchments (with catchment areas ranging from $<1$ to $160 \mathrm{~km}^{2}$ ) had ERs ranging from 1.5 to 7.8 [17-21] and the highest value of 16 was found in a $1.3 \mathrm{~km}^{2}$ peat land catchment in Scotland [17].
The highest values are likely associated with substantial lateral convey of soil $\mathrm{CO}_{2}$ from the terrestrial ecosystem to the stream networks [18-21]. Large river networks (areas $>7.5 \times 10^{4} \mathrm{~km}^{2}$ ) in temperate regions generally had higher ERs than rivers in tropical regions: $2-5$ versus $\sim 1$ [1,7,12,22-24] (Table 1 ). This 2-to-5fold difference suggests temperate rivers released higher portions of terrestrial NPP to the atmosphere than tropical rivers as to tropical ecosystems despite lower areal extents of the temperate rivers (Table 1). This is thought to be related to significantly lower terrestrial NPP in temperate than in tropical ecosystems [25-27]; carbon emission rates were however comparable between temperate and tropical rivers (Table 1).

Table 1: A synthesis of $\mathrm{CO}_{2}$ emission from river networks and its relationship with regional terrestrial NPP.

\begin{tabular}{|c|c|c|c|c|c|c|c|}
\hline Stream $\backslash$ River & $\begin{array}{c}\text { Region / } \\
\text { Catchment } \\
\text { Area* } \\
\left(\mathrm{km}^{2}\right)\end{array}$ & $\begin{array}{l}\text { Stream } \\
\text { Order }\end{array}$ & $\begin{array}{c}\text { Region / } \\
\text { Catchment } \\
\text { Terrestrial } \\
\text { NPP }(\mathrm{Tg} \\
\mathrm{yr}_{-1} \text { ) } \\
\end{array}$ & $\begin{array}{c}\text { Mean Water } \\
\text { Surface } \mathrm{CO}_{2} \\
\text { Emission } \\
\text { Rate }^{*}(\mathrm{~g} \\
\left.\mathrm{Cm}^{-2} \mathrm{yr}^{-1}\right)\end{array}$ & $\begin{array}{c}\text { Ratio of River } \\
\text { Surface Area } \\
\text { to Region / } \\
\text { Catchment } \\
\text { Area* (\%) }\end{array}$ & $\begin{array}{c}\text { Ratio of Carbon } \\
\text { Emission from } \\
\text { Rivers to Regional } \\
\text { Terrestrial NPP } \\
(\%)\end{array}$ & $\begin{array}{c}\text { Elevation } \\
\text { Ratio } \Delta\end{array}$ \\
\hline \multicolumn{8}{|c|}{ Streams } \\
\hline $\begin{array}{l}\text { West Fork of Walker Branch, } \\
\text { Tennessee }\end{array}$ & 0.38 & 1 & $1.9 \times 10^{-4}$ & 1104 & 0.26 & 0.4 & 1.5 \\
\hline $\begin{array}{l}\text { Rocky Burn Stream near Aberdeen, } \\
\text { Scotland }\end{array}$ & 1.3 & 1 & $6.5 \times 10^{-4}$ & 8428 & 0.17 & 2.8 & 16 \\
\hline $\begin{array}{l}\text { Streams near Juruena in Mato } \\
\text { Grosso, Brazil }\end{array}$ & 6 & $1-2$ & $4.8 \times 10^{-3}$ & 2271 & 1.8 & 4.97 & 2.8 \\
\hline $\begin{array}{c}\text { Streams at Tanguro Ranch, Mato } \\
\text { Grosso, Brazil }\end{array}$ & 13.2 & 1 & $1.1 \times 10^{-2}$ & 5994 & 0.007 & 0.055 & 7.8 \\
\hline $\begin{array}{c}\text { Streams in Paragominas, Pará, } \\
\text { Brazil }\end{array}$ & $32.5-161$ & - & 26.6 & - & 0.15 & $0.25-0.5$ & $1.7-3.3$ \\
\hline \multicolumn{8}{|c|}{ Tropical River Networks } \\
\hline Ji-Paraná River at Rondônia, Brazil & 75400 & $3-6$ & 61 & 2233 & 0.45 & 0.47 & 1 \\
\hline Mekong River & $7.95 \times 10^{5}$ & - & 639 & 852 & 1 & 1.1 & 1.1 \\
\hline Amazon River & $1.8 \times 10^{6}$ & $?-12$ & 3180 & 830 & 14.3 & 14.9 & 1 \\
\hline \multicolumn{8}{|c|}{ Temperate River Networks } \\
\hline Yellow River, China & $7.5 \times 10^{5}$ & $1-6$ & 372 & 1065 & 0.4 & 0.72 & 1.8 \\
\hline Sweden streams and rivers & $4.5 \times 10^{5}$ & $1-5$ & 171 & $473-3032$ & 0.1 & 0.5 & 5 \\
\hline $\begin{array}{l}\text { Conterminous US streams and } \\
\text { rivers } \\
\end{array}$ & $7.8 \times 10^{6}$ & $1-10$ & $3.860 \times 10^{3}$ & $882-4008$ & 0.52 & 2.5 & 4.8 \\
\hline \multicolumn{8}{|c|}{ Global Estimates } \\
\hline Globalo & $1.33 \times 10^{8}$ & - & $5.35 \times 10^{4}$ & $890-2880$ & 0.47 & $1.0-3.4$ & $2.1-7.2$ \\
\hline
\end{tabular}

*Data of catchment area, water surface area, and carbon emission rate were obtained from ref. 1, 6, 7, 12, 17-24. $\triangle \mathrm{NPP}$ for conterminous US is obtained from supplementary ref. 25 , and its area-averaged value $\left(495 \mathrm{~g} \mathrm{~m}^{-2} \mathrm{yr}^{-1}\right)$ is used for calculating regional NPP in temperate basins (the Yellow River basin, the Scotland and Tennessee stream); NPP for the Amazon basin is obtained from ref. 26 (by proportioning relevant NPP to the studied area in ref. 1), and its area-averaged value $\left(804 \mathrm{~g} \mathrm{~m}^{-2} \mathrm{yr}^{-1}\right)$ is used for calculating NPP of rivers in the same region (the Brazilian streams and rivers) and the tropical Mekong River; NPP for Sweden $\left(380 \mathrm{~g} \mathrm{~m}^{-2} \mathrm{yr}^{-1}\right)$ is obtained from ref. 27 (area-averaged NPP was used in order that different land uses are equally represented). $\Delta=$ Ratio of river water surface to catchment area / Ratio of $C$ emission from rivers to regional NPP. $\circ$ Antarctic is excluded from the Earth land surface area; global terrestrial NPP is obtained from supplementary ref. 26; global $\mathrm{C}$ emission $\left(0.56-1.8 \mathrm{Pg} \mathrm{yr}^{-1}\right)$ from streams and rivers are obtained from ref. 2, 3, 6; area of global streams and rivers are obtained from ref. 6. 
This analysis suggests $\mathrm{CO}_{2}$ emission from streams and rivers comprises a variable part of terrestrial carbon fluxes, representing $<1-16 \%$ of terrestrial NPP depending on different spatial scales and climates. Considering higher carbon emission from streams and rivers than expected from their areal extent on the landscape (i.e., ER > 1), it is suggested that carbon emission from rivers represents an elevated portion of terrestrial carbon release to the atmosphere in comparison to other terrestrial carbon fluxes. Globally, about $0.47 \%$ of the Earth surface occupied by fluvial channels released carbon in quantities representing $1.0-3.4 \%$ of the global terrestrial NPP (Table 1). Despite a still large uncertainty in current estimates of the $\mathrm{CO}_{2}$ emission fluxes from global streams and rivers (0.56-1.8Pg C yr $\left.{ }^{-1}\right)[2,3,6]$, available data clearly highlight streams and rivers as hotspot of carbon emission from the terrestrial landscape. Neglecting $\mathrm{CO}_{2}$ emission from streams and rivers in land-atmosphere carbon exchanges (for instance, the Intergovernmental Panel on Climate Change 2007 (IPCC 2007) report omitted carbon released from global inland waters; the new IPCC 2013 report has however included this carbon flux), therefore, misses a small but disproportionally active player in the global carbon cycle.
Elevated carbon emission from streams and rivers is thought to be related to disproportional transfer of terrestrial carbon to these inland waters during hydrological processes (Figure 1). First, $\mathrm{CO}_{2}$ produced by heterotrophic degradation of organic carbon in soils and plant root respiration accumulates to high concentrations in soils due to limited gas diffusivity and ventilation $[18,20]$. Soil $\mathrm{CO}_{2}$ is however easily mobilized and incorporated into local streams and rivers, sustaining high carbon emissions especially from streams and small rivers which are of high connectivity to the terrestrial ecosystem and make up a significant portion of the river network [6-8]. Second, there is a differential effect for soil organic carbon whereby lighter and organic-rich soils are preferentially mobilized, leached and transported to streams and rivers during hydrological processes, resulting in a relative enrichment of land-sourced labile organic carbon in rivers [28]. Degradation of river organic carbon is further facilitated by favourable aquatic conditions (e.g. rich microbial biodiversity) that allow for efficient mineralization river organic carbon during transport $[8,10]$. Finally, high turbulence in streams and rivers allows for quick evasion of the gas to the atmosphere in comparison with soils that are relatively less frequently disturbed [7,21,29] (Figure 2).

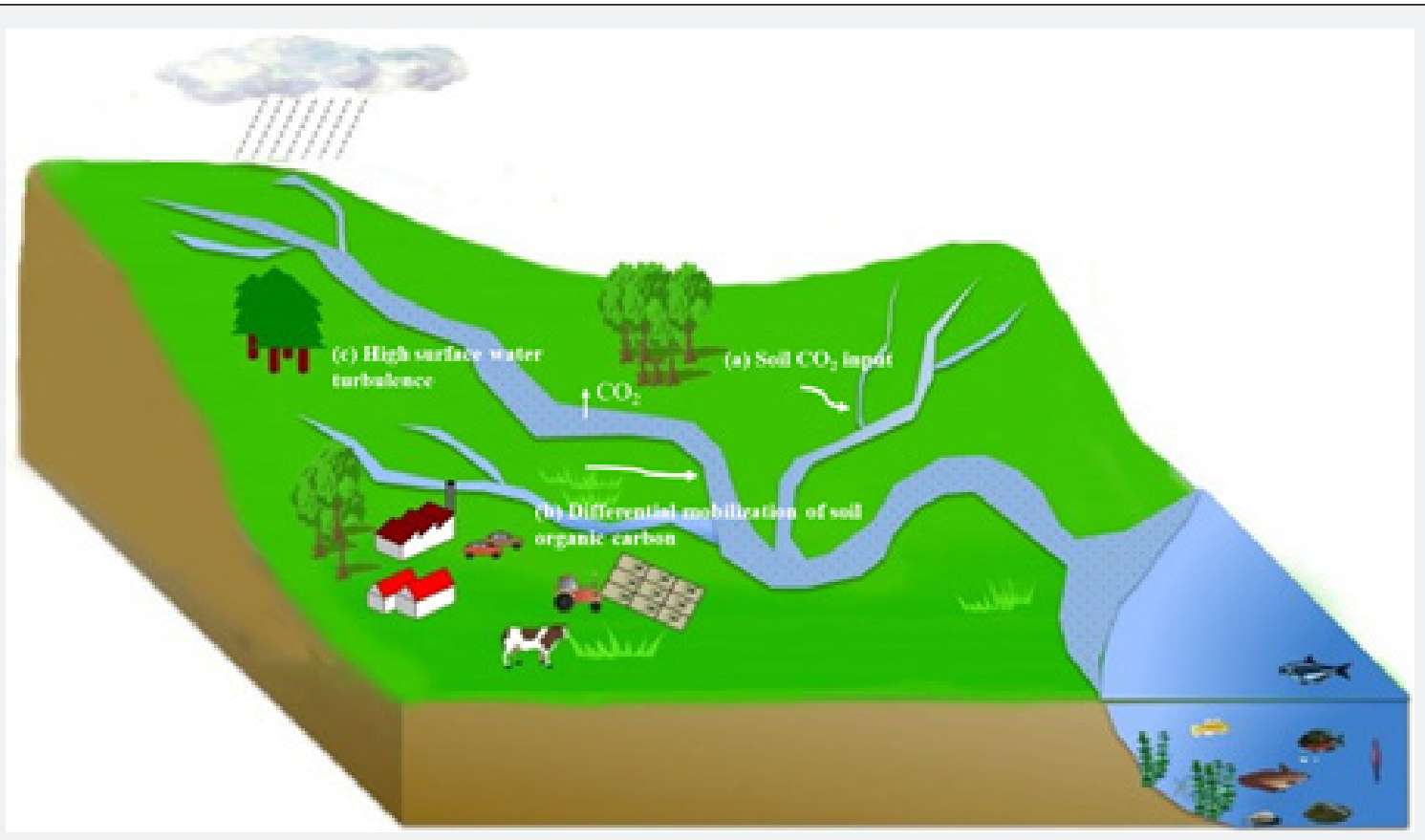

Figure 1: $\mathrm{CO}_{2}$ emission from streams and rivers as an integrative part of terrestrial respiration. The disproportional role of streams and rivers in emitting terrestrial carbon to the atmosphere is strengthened by (a) high input of soil $\mathrm{CO}_{2}$ to streams and small rivers, (b) differential transport of organic rich soils to streams and rivers and (c) high turbulence in streams and rivers that facilitates quick evasion of the gas to the atmosphere.

In a sense, excess $\mathrm{CO}_{2}$ emission from streams and rivers represents a part of the terrestrial carbon that is released under mediation of the flowing surface waters of the Earth and is further deduced to vary spatially with the spatial extent of these waters. In this case, a strong positive relationship was found between the areal extent of river networks and rate of riverine carbon emission normalized to catchment area or the ratio of riverine carbon emission to terrestrial NPP $\left(R_{2}=0.85\right.$ and 0.75 , respectively) (Figure 2), suggesting hydrology as the primary driver of the carbon emission from streams and rivers $[7,30]$. 


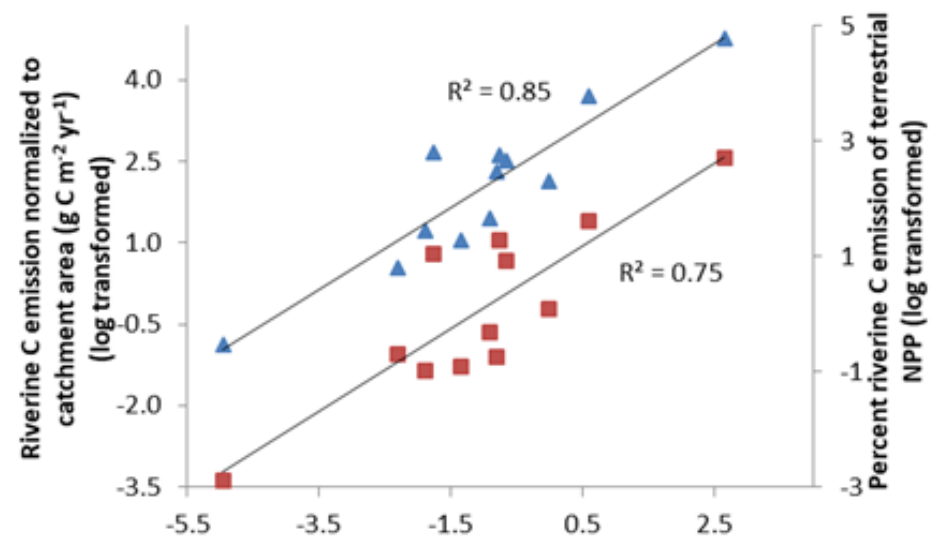

Areal percentage of river channels (log transformed)

Figure 2: Positive correlations between areal extent of river networks and riverine carbon emission rate normalized to catchment area $(\boldsymbol{\Delta})$ and percentage riverine carbon emission of annual terrestrial NPP ( $\mathbf{\bullet})$. Riverine carbon emission rate normalized to catchment area was calculated as the total amount of $\mathrm{CO}_{2}$ emission from rivers $\left(\mathrm{g} \mathrm{C} \mathrm{yr}^{-1}\right)$ divided by catchment area $\left(\mathrm{m}^{2}\right)$. Percentage riverine carbon emission of annual terrestrial NPP was calculated as the total amount of $\mathrm{CO}_{2}$ emission from rivers $\left(\mathrm{g} \mathrm{C} \mathrm{rr}^{-1}\right)$ divided by catchment terrestrial NPP $(\mathrm{g}$ ( $\left.\mathrm{yr}^{-1}\right)$. All data were natural log transformed.

To summarize, a framework that links $\mathrm{CO}_{2}$ emission from streams and rivers to terrestrial carbon fluxes was proposed for a better understanding of the role of streams and rivers in global carbon cycle. Emission of $\mathrm{CO}_{2}$ from riverine channels represents an elevated portion of terrestrial carbon that is released to the atmosphere by streams and rivers; however, mechanisms that dictate the elevated role of streams and rivers in terrestrial carbon cycle are still uncertain. New comparative studies of ecological functions of terrestrial soils and inland waters would help resolve this problem.

\section{Acknowledgement}

I would like to acknowledge Dr. Ting Liu for her help on creating illustrations in Figure 1.

\section{References}

1. Richey JE, Melack JM, Aufdenkampe AK, Ballester VM, Hess LL (2002) Outgassing from Amazonian rivers and wetlands as a large tropical source of atmospheric $\mathrm{CO}_{2} \cdot 416(6881): 617-620$

2. Aufdenkampe AK, Mayorga E, Raymond PA, Melack JM, Doney SC, et al. (2011) Riverine coupling of biogeochemical cycles between land, oceans, and atmosphere. Front Eco Environ 9(1): 53-60.

3. Battin TJ, Luyssaert S, Kaplan LA, Aufdenkampe AK, Richter A, et al. (2009) The boundless carbon cycle. Nature Geosci 2(9): 598-600.

4. Regnier P, Friedlingstein P, Ciais P, Mackenzie FT, Gruber N, et al. (2013) Anthropogenic perturbation of the carbon fluxes from land to ocean. Nature Geosci 6: 597-607.

5. Cole J, Prairie YT, Caraco NF, McDowell WH, Tranvik LJ, et al. (2007) Plumbing the global carbon cycle: integrating inland waters into the terrestrial carbon budget. Ecosystems 10(1): 172-185.

6. Raymond PA, Hartmann J, Lauerwald R, Sobek S, McDonald C, et al. (2013) Global carbon dioxide emissions from inland waters. Nature 503(7476): 355-359.
7. Butman D, Raymond PA (2011) Significant efflux of carbon dioxide from streams and rivers in the United States. Nature Geosci 4(12): 839-842.

8. Hotchkis, ER, Hall RO, Sponseller RA, Butman D, Klaminder J, et al. (2015) Sources of and processes controlling CO2 emissions change with the size of streams and rivers. Nature Geosci 8(9): 696-699.

9. Mayorga E, Aufdenkampe AK, Masiello CA, Krusche AV, Hedges JI, et al. (2005) Young organic matter as a source of carbon dioxide outgassing from Amazonian rivers. Nature 436(7050): 538-541.

10. Battin TJ, Kaplan LA, Findlay S, Hopkinson CS, Marti E, et al. (2008) Biophysical controls on organic carbon fluxes in fluvial networks. Nature Geosci 1(2): 95-100.

11. Cole JJ, Caraco NF (2001) Carbon in catchments: connecting terrestrial carbon losses with aquatic metabolism. Mar Freshwater Res 52(1): 101-110.

12. Humborg C, Mörth CM, Sundbom M, Borg H, Blenckner T, et al. (2010) $\mathrm{CO}_{2}$ supersaturation along the aquatic conduit in Swedish watersheds as constrained by terrestrial respiration, aquatic respiration and weathering. Global Change Biol 16(7): 1966-1978.

13. Lapierre JF, Guillemette F, Berggren M, del Giorgio P (2013) Increases in terrestrially derived carbon stimulate organic carbon processing and $\mathrm{CO}_{2}$ emissions in boreal aquatic ecosystems. Nat Commun 4: 2972.

14. Maberly SC, Barker PA, Stott AW, De Ville MM (2013) Catchment productivity controls $\mathrm{CO} 2$ emissions from lakes. Nature Clim Change 3(4): 391-394.

15. Randerson J, Chapin FS, Harden JW, Neff JC, Harmon ME (2002) Net ecosystem production: a comprehensive measure of net carbon accumulation by ecosystems. Ecol Appl 12(4): 937-947.

16. Lovett GM, Cole JJ, Pace ML (2006) Is net ecosystem production equal to ecosystem carbon accumulation? Ecosystems 9(1): 152-155.

17. Hope D, Palmer SM, Billett MF, Dawson JJC (2001) Carbon dioxide and methane evasion from a temperate peatland stream. Limnol Oceanogr 46(4): 847-857. 
18. Jones JB, Mulholland PJ (1998) Carbon dioxide variation in a hardwood forest stream: an integrative measure of whole catchment soil respiration. Ecosystems 1(2): 183-196.

19. Neu V, Neill C, Krusche AV (2011) Gaseous and fluvial carbon export from an Amazon forest watershed. Biogeochemistry 105(1-3): 133147

20. Johnson MS, Lehmann J, Riha SJ, Krusche AV, Richey JE, et al. (2008) $\mathrm{CO}_{2}$ efflux from Amazonian headwater streams represents a significant fate for deep soil respiration. Geophys Res Lett 35(17): L17401.

21. Davidson EA, Figueiredo RO, Markewitz D, Aufdenkampe AK (2010) Dissolved $\mathrm{CO}_{2}$ in small catchment streams of eastern Amazonia: A minor pathway of terrestrial carbon loss. J Geophys Res Biogeosciences 115(G4): G04005.

22. Ran L, Xi Xi Lu, Huan Yang, Lingyu Li, Ruihong Yu, et al. (2015) $\mathrm{CO}_{2}$ outgassing from the Yellow River network and its implications for riverine carbon cycle. Journal of Geophysical Research: Biogeosciences 120(7): 1334-1347.

23. de Fátima FL Rasera M, Ballester MVR, Krusche AV (2008) Estimating the surface area of small rivers in the Southwestern Amazon and their role in $\mathrm{CO}_{2}$ outgassing. Earth Interact 12(6).

24. Li S, Lu XX, Bush RT (2013) $\mathrm{CO}_{2}$ partial pressure and $\mathrm{CO}_{2}$ emission in the Lower Mekong River. J Hydrol 504: 40-56.
25. Felzer B, Kicklighter D, Melillo J, Wang C, Zhuang Q, et al. (2004) Effects of ozone on net primary production and carbon sequestration in the conterminous United States using a biogeochemistry model. Tellus B 56(3): 230-248.

26. Potter C, Klooster S, Genovese V (2012) Net primary production of terrestrial ecosystems from 2000 to 2009. Climatic Change 115(2): 365-378.

27. Morales P, Hickler T, Rowell DP, Smith B, Sykes MT, et al. (2007) Changes in European ecosystem productivity and carbon balance driven by regional climate model output. Global Change Biol 13(1): 108-122.

28. Wang Z, Govers G, Steegen A, Clymans W, den Putte AV, et al. (2010) Catchment-scale carbon redistribution and delivery by water erosion in an intensively cultivated area. Geomorphology 124(1-2): 65-74.

29. Kokic J, Sahlée E, Sobek S, Vachon D, Wallin MB, et al. (2018) High spatial variability of gas transfer velocity in streams revealed by turbulence measurements. Inland Waters, pp. 461-473.

30. Liu S, Raymond PA (2018) Hydrologic controls on $\mathrm{pCO}_{2}$ and $\mathrm{CO}_{2}$ efflux in US streams and rivers. Limnology and Oceanography Letters 3(6): 428-435.

\section{Your next submission with Juniper Publishers will reach you the below assets}

- Quality Editorial service

- Swift Peer Review

- Reprints availability

- E-prints Service

- Manuscript Podcast for convenient understanding

- Global attainment for your research

- Manuscript accessibility in different formats ( Pdf, E-pub, Full Text, Audio)

- Unceasing customer service

Track the below URL for one-step submission https://juniperpublishers.com/online-submission.php 